\title{
Chapter 3 \\ Promoting Jatropha Agriculture for Sustainable Soil Capital Improvement: A Win-Win Technology for Rehabilitating Degraded Lands in Africa
}

\author{
Joshua O. Ogunwole, Olufunmilola Alabi, Omadachi Ugbabe, \\ and Birhanu Z. Birhanu
}

\begin{abstract}
A significant decline in soil quality has occurred across Sub-Saharan Africa (SSA) through adverse changes in soil properties causing serious challenge to regional food security. This paper presents the new Jatropha technology for soil quality improvement and its importance for meeting rural energy demand in SSA. The paper starts from the premise of Jatropha agriculture and its impact on soil quality improvement with reference to examples from the drylands of Nigeria and Mali. Having reviewed the sweeping claims on Jatropha's role and ability as alternative energy source, its 'alleged' cheap domestication and rush for mega plantations of Jatropha, the paper weighs the controversies surrounding the sustainable production, land grabbing and consequent economics of Jatropha productivity in mega plantation settings. It suggests the need to focus Jatropha agriculture and research in SSA toward rehabilitation of degraded lands, wastelands and badlands while, promoting Jatropha hedge-row fencing for small-holder farming. In addition to technical availability in terms of soil improvement and seed yield, it is suggested that indiscriminate tree-felling for fuel wood in SSA can be checked through a shift from current petrochemical technologies to biodiesel alternatives. The main conclusion is that first, SSA must consider as germane, a natural resource improvement approach based on a new green and bioenergy revolution, and secondly that a
\end{abstract}

\footnotetext{
J. O. Ogunwole (四)

Department of Environmental Management and Crop Production, Bowen University,

Iwo, Nigeria

O. Alabi · O. Ugbabe

Faculty of Agriculture, Ahmadu Bello University, Zaria, Nigeria

B. Z. Birhanu

ICRISAT, West and Central African station, Bamako, Mali

(C) Springer Nature Switzerland AG 2019

E. T. Ayuk and N. F. Unuigbe (eds.), New Frontiers in Natural Resources Management in Africa, Natural Resource Management and Policy 53,

https://doi.org/10.1007/978-3-030-11857-0_3
} 
regional, pro-active and strategic direction is required to promote Jatropha research for innovation to deliver solutions to addressing the hydra-head environmental challenge of declining soil quality and fuel wood scavenging in the region.

Keywords Jatropha curcas L. Carbon sequestration · Soil physical quality · Green economy

\subsection{Introduction}

Natural resource degradation due to poor land use decisions continues to threaten the livelihoods of millions of people globally with annual estimated losses in agricultural production put at approximately US $\$ 40$ billion. The United Nations Convention to Combat Desertification (UNCCD) was commissioned as a global response to the challenging need to address desertification processes in sub-Saharan Africa (SSA) and other drylands of the world. The UNCCD was negotiated to address land degradation (including, soil degradation) in those regions; placing emphasis on social and economic as much as environmental issues (Montanarella and Alva 2015). The convention defines land degradation as a "reduction or loss in arid, semi-arid and dry sub-humid areas, of the biological or economic productivity and complexity of rainfed croplands, irrigated cropland or range, pasture, forest and woodlands resulting from land uses or from a process or combination of processes, including processes arising from human activities and habitation patterns, such as, (i) soil erosion caused by wind and/or water, (ii) deterioration of the physical, chemical and biological or economic properties of soil; (iii) long term loss of natural vegetation" (article 1f, UNCCD 1994). The SSA's ecologies are characterized by fragile and vulnerable ecosystems; poor soils derived from acidic or acolian parent materials which are low in clay content, having a coarse-textured soil surface with an equally low water and nutrient holding capacities. Desertification and degradation risks, characterized by anomalous increase in temperature and associated biodiversity loss, food insecurity, water scarcity and an increase in drought frequency are the dominant features of the ecological landscapes. Further, natural resource degradation such as forest depletion and looming water scarcity, brought about by changes in land-use and; unsustainable agricultural production practices, depletion of biological resources and sharp decline in various indicators of wellbeing are accumulating cascade of factors that have precipitated natural resource degradation crises on these landscapes.

Past mismanagement of these natural resources in agricultural production has reduced the sustainability of most of the continent's ecosystems. Land degradation is particularly acute covering two-thirds of agricultural lands and a third of permanent pastures (Scherr and Yadav 1996). Here, land use profoundly influences soil functions at all levels within natural and managed ecosystems and; these functions 
further influence ecological sustainability. Major causes of land degradation in SSA are soil erosion and soil fertility depletion. Decades of agricultural extensification practiced by smallholder farmers in SSA that resulted in the conversion of most vegetated lands to agricultural land use contributed to increasing atmospheric greenhouse gas emission; as well as depleting soil fertility and declining soil quality (Lal 2004). Coupled with farmers' practices are climate change and population pressures that are putting unprecedented pressure on the soils of the SSA. According to a report of UNEP (2012), this pressure has created three regional challenges for the African soils namely: (1) the need to double food supplies and increase fuel (including fuel from renewable biomass); (2) the need to increase supply of water by more than $50 \%$ for drinking, agriculture and other uses and; (3) the need to mitigate and adapt to climate change and biodiversity loss characteristic of the landscapes. One urgent priority for action is to ensure that the soils will cope with the multiple and increasing demand. Therefore, the sustainable management of soil resources is an important pre-requisite for increased ecosystem productivity and maintenance of an ecological balance.

The current soil management paradigm has to change from improving chemical fertility to practices that mimic the natural ecosystems from which existing agricultural systems develop (Ogunwole 2009; Craswell and Lefrog 2001). Biological soil management and conservation practices that produced acceptable yield and increase carbon and nitrogen inputs to soils and complement soil water retention are desirable traits in land rehabilitation and development programmes; as the practices address both soil erosion and fertility decline (Stocking 2003). These biological soil management and conservation practices are expected to improve soil structural stability, increase soil organic matter (SOM) accumulation; enhance soil fertility and buildup soil quality. Against a background of land (and/or soil) management narratives that are being suggested as best practices for land improvement and productivity, there is an increasing body of literature that proposes a natural resource improvement approach based on a new green and bioenergy revolution. (Ogunwole 2014; Halilu et al. 2011; Bekunda et al. 2009). One of the green and bioenergy initiatives is the promotion of Jatropha agriculture (Ogunwole 2014). Jatropha curcas L. commonly referred to as physic nut belongs to the family Euphorbiaceae. It is a hardy perennial shrub that grows in the wild. It is not browsed by livestock and yields non-edible oil, which can be used directly or after trans-esterification, as biodiesel in engines. The shrub is said to be well adapted to growing on marginal and degraded lands, as a fence or protection hedge of cultivated lands from animals and erosion.

In this paper, we diagnosed poor soil productivity and inappropriate soil management practices by locals as a driver of poverty and food insecurity that is prevalent in SSA. We examined the hypes, current issues and gaps in Jatropha and its agriculture. We identified ways and steps to ensure that Jatropha agriculture becomes a win-win technology and highlighted areas of research focus to develop the shrub's agriculture. 


\subsection{Case Study: Jatropha Biofuels, Agriculture and Environment}

Increasing global concern over fluctuations in the price and supply of fossil fuels, global warming from greenhouse gas emission and the growing energy demand coupled with the need for domestic energy security has drawn attention to bio-fuels and bio-energy crops as sustainable alternative energy source. With an already growing global population, estimated to be about nine billion people by the year 2050 (United Nations 2003), enormous pressure will be on the Earth's land to provide food, fuel and fibre for the teaming population. Per capita food consumption is projected to increase from $2808 \mathrm{Kcal} /$ person/day in 1997-1999 to $3050 \mathrm{Kcal} / \mathrm{per}-$ son/day by 2030 (Bustamante et al. 2008; FAO 2006); all of which add pressure to the food supply system. Some of the increased supply will come from improved crop yields per unit area while; bringing more lands to cultivation will account for the remainder. Further demand for land will arise from the need to expand land dedicated to bio-fuels so as to increase biomass-based fuels; increased demand for more wood products and the need for more carbon storage will increase competition for land. Overarching all these needs is the threat of the effects of climate change, aquaculture, urbanization and land degradation. In a world seeking solution to its energy, environmental and food challenges, society cannot afford to miss out on the global greenhouse gas emission reductions and the local environmental and societal benefits when bio-fuels are done right (Tilman et al. 2009).

Bio-fuels, unlike fossil fuels, have many advantages that include, their renewable source that will not be depleted thus providing energy security, their ability to provide employment both at feedstock production and processing into fuel and, the saving from import bills of fossil fuels by non-petroleum producing countries (Biswas et al. 2010). Lots of controversy however, surround the bio-fuels-agricultureenvironment linkage and this linkage is replete with environmental narratives of bio-fuel feed stock pressure reshaping land use and resulting in natural resource degradation. One instance is the deforestation of large expanse of land in Kusawgu, northern Ghana for development of bio-fuel plantation by a Norwegian bio-fuel company. Proponents of bio-fuels development argued that aside providing energy security; bio-fuels will be capable of addressing the twin problems of poverty and climate change (Peskett et al. 2007). On the other hand, the other stakeholders cautioned that production of bio-energy crops may compete with food crops for scarce agricultural lands, pushing up food prices and increasing land values (while promoting land grabs) which may adversely affect the poor (Godfray et al. 2010).

\subsubsection{Jatropha curcas L: From Obscurity to Celebrity}

By the year 2000, Jatropha curcas L fast tracked itself from obscurity to prominence due principally to the quality of its methyl ester that was a potential biodiesel. The pioneering studies involving DaimlerChrysler AG, University of 
Hohenheim, Germany and the Central Salt Marine Chemical Research Institute, India; showed unambiguously the high-quality Jatropha methyl ester or bio-diesel to conform to EN 14214 specifications, thus exhibiting drastically reduced emission (Ghosh et al. 2007). Therefore,Jatropha's prominence is neither because of the fact that its oil is non-edible nor that it can grow on wasteland but its inherent advantages in the process of oil compared to other oils. When the environmental impact of Jatropha biodiesel was compared to the lifecycle impacts of a fossil fuel reference system delivering same amount of product and functions as the Jatropha bio-diesel, the use of Jatropha bio-diesel resulted in $82 \%$ decrease in non-renewable energy requirement and a 55\% reduction in global warming potential (Achten et al. 2010).

By the year 2003, a lot of theories had been created around the shrub tagging it a 'wonder plant' or 'miracle crop' and igniting controversy (Burley and Griffiths 2009). Sweeping claims made on the role and ability of the shrub, devoid of any scientific investigations, abound that Jatropha can tolerate drought conditions hence, can grow in arid (200 $\mathrm{mm}$ rainfall) as well as higher rainfall zones (Jain and Sharma 2010); it grows well on any soil type with little or no fertilizers required (Ogunwole 2014) and yields an average of $3.8 \mathrm{t} / \mathrm{ha}$ with oil content of 30-35\% giving a yield of $1.3 \mathrm{t} / \mathrm{ha}$ (Singh et al. 2014). Jatropha was perceived as quick yielding, pests and disease resistant and grows relatively quickly, producing seeds for 50 years (Mittlelbach 1996); the shrub can promote poverty reduction (Peskett et al. 2007) and perform environmental functions (Sieg 2006). At the time of these claims however, there was neither any quantitative information on the potential impact of mega plantation of Jatropha curcas on natural resource nor was there anything to show its potentials for land degradation mitigation and poverty alleviation. Globally as at then, Jatropha curcas L. was only being domesticated and yield was not predictable. The condition that best suits its growth was only being investigated and; the potential impacts of large-scale cultivation were not fully understood. The enthusiasm that followed the Jatropha plant prompted Fairless (2007) to caution against 'any premature push to promote large scale cultivation without the necessary research support on its basic agronomics' as it could lead to very unproductive agriculture.'

\subsubsection{Jatropha Agriculture}

It is pertinent to note that survival ability of Jatropha under marginal conditions does not imply that high productivity can be obtained. The shrub grows well in areas with rainfall of 1000-1500 mm per annum, day light insensitive and prefers well drained, aerated soils. It can neither withstand water logging, shade (Sahoo et al. 2009) nor very high precipitation. Optimum temperature ranges from $20^{\circ} \mathrm{C}$ to $28^{\circ} \mathrm{C}$, as very high temperature depresses yield. The shrub can tolerate alkaline $\mathrm{pH}$ but does well within $\mathrm{pH}$ 6.0-8.0. Planting materials are usually selected from cuttings or seeds that are high yielding both in terms of seed weight and seed oil content. Large seeds from mature yellow or brown fruits (capsule) can be selected for sowing. Seeds are usually soaked in cold water for $12-24 \mathrm{~h}$ as pre-treatment to soften the seed coat to enhance germination. During soaking pre-treatments, only seeds that sink in water 
are selected for sowing; neither floating seeds nor seeds with broken caruncle (tip) are viable for sowing. After cold water pre-treatment, seeds are transferred to watersoaked jute sacks, covered and kept well-watered. Germination starts from the third day through to 2 weeks. As seeds germinate, they are transferred to seedling bags; previously filled with sand-soil-manure at either ratio $1: 1: 1$ or $1: 1: 2$ and wellwatered. This approach ensures approximately 100\% emergence of germinating seeds and reduces chance of re-seeding. Another option is direct seeding into the field; this operation is carried out at the commencement of the rainy season. Two seeds are planted per hole at 4-6 cm depth which should later be thinned to two. This system increases seed rates; on the average, 1300 seeds weigh approximately $1 \mathrm{~kg}$; the seed rate for planting $1 \mathrm{ha}$ (at 2500 plants per ha) is about $4 \mathrm{~kg}$ in the case of direct seeding. In determining planting densities (i.e. spacing for the shrub), consideration must be given to access for workers and implements. For instance, ease of passage by fruit pickers must be considered in determining spacing for the plantation. Further, access to cart during harvest and weed control must be considered where applicable. Competition among shrubs for water, light and nutrients must be considered. Planting densities range from 1100 to 2500 plants per hectare.

Behera et al. (2010) observed no significant difference in plant performance amongst $2 \mathrm{~m} \times 2 \mathrm{~m}$ and $3 \mathrm{~m} \times 3 \mathrm{~m}$ spaced plant. In Nigeria, we studied the effect of spacing on plant height, canopy width and yield in a 2-year old Jatropha; no consistent trend was observed in all the measured plant parameters (Table 3.1), and thus too early to make inference on the basis of preliminary results as in this case. In most plantations elsewhere however; $2500(2 \mathrm{~m} \times 2 \mathrm{~m})$ plants per hectare have been adopted long before the release of any trial result. Holes of $30 \mathrm{~cm}$ width and depth are normally prepared after laying out the field and farm yard manure is usually incorporated with the excavated soil (plus insecticide in termite populated fields) prior to transplanting of seedling.

Once the plant is established, the leading shoot may grow up to $100 \mathrm{~cm}$ within 6 months; reducing the height of stem and branches at this point through pruning is vital. Pruning and canopy management is an important architectural intervention in Jatropha cultivation. Pruning helps to keep shrub's height at harvestable distance and, increases fruiting by promoting development of lateral branches due to the suppression of apical dominance. Traditionally, manual pruning, during the non-rainy season, at $30 \mathrm{~cm}$ height from the ground had been reported to promote crown area (Behera et al. 2010). However, reduction in fruiting has also been reported with manual pruning in dryland India. Cost, convenience and efficiency of manual pruning in

Table 3.1 Effect of spacing on performance of 2-year-old Jatropha curcas L. at Samaru, Nigeria

\begin{tabular}{l|l|l|l|l|l}
\hline Spacing & $\begin{array}{l}\text { Plant height } \\
(\mathrm{cm})\end{array}$ & $\begin{array}{l}\text { Canopy width } \\
(\mathrm{cm})\end{array}$ & $\begin{array}{l}\text { 2010 Capsule } \\
\text { yield }(\mathrm{kg} / \mathrm{ha})\end{array}$ & $\begin{array}{l}\text { 2011 Capsule } \\
\text { yield }(\mathrm{kg} / \mathrm{ha})\end{array}$ & $\begin{array}{l}\text { Oil content } \\
(\%)\end{array}$ \\
\hline $1.5 \mathrm{~m} * 1.5 \mathrm{~m}$ & 43.8 & 58.3 & 88.6 & 296.3 & 37.3 \\
\hline $\begin{array}{l}1.5 \mathrm{~m} * \\
2.0 \mathrm{~m}\end{array}$ & 39.0 & 44.0 & 42.8 & 220.9 & 37.9 \\
\hline $\begin{array}{l}1.5 \mathrm{~m} * \\
1.0 \mathrm{~m}\end{array}$ & 40.7 & 51.7 & 92.6 & 383.1 & 37.3 \\
\hline $2.0 \mathrm{~m} * 2.0 \mathrm{~m}$ & 37.2 & 51.2 & 40.4 & 89.1 & 36.4 \\
\hline
\end{tabular}


mega plantations of Jatropha will be a major challenge. Studies on the use of plant growth regulators (PGR) have been on-going and reports have it that PGR like 2, 3, 5- triiodobenzoic acid produced more flowers per plant, more fruits per bunch and, heavier fruits with higher oil compared to manual and zero pruning in South Africa; when foliar applied on a 1-year-old Jatropha plant (Abdelgadir et al. 2010). Experiments involving pruning of Jatropha in Gujarat, India showed manual pruning resulting in capsule yield reduction of about $98 \%$ while; application of PGR, Paclobutrazol, to pruned Jatropha shrub induced flowering and fruiting limiting capsule yield reduction to $67 \%$ (Ghosh et al. 2011).

Intercropping Jatropha with other crops at the early growth stage of the shrub can ensure weed suppression and provide farmers with food and income. At Samaru in Nigeria, capsule yield of 2-year-old Jatropha was not affected by intercropping with legumes and oilseeds (Table 3.2). Cowpea with >95 days of physiological maturity; groundnuts with 100 days' maturity and soybean with $<105$ days' maturity recorded high yields when intercropped with Jatropha (Table 3.2). Fertilizer application is essential for planted Jatropha, the nutrient requirement for the plant is not yet known. However, 3-5 t/ha farm yard manure or Jatropha seed cake, $60 \mathrm{~kg} / \mathrm{ha}_{2} \mathrm{O}_{5}$ and $60-120 \mathrm{~kg} \mathrm{~N} / \mathrm{ha}$ (Table 3.3) have been used in Jatropha plantation in CSMCRI, India (Ogunwole et al. 2008). Capsules are harvested by hand picking, when capsule colour changes from green to yellow to brown. Ripening of capsule is not uniform hence weekly picking of ripe fruits is done till end of harvest. Capsules are sun-dried for days and seeds removed from the fruit shell by hand or crushed with a wooden board. Viability of harvested Jatropha seeds can be maintained for 7-8 months, if stored in ambient condition. Long storage beyond 8 months affects

Table 3.2 Yields of legumes, oil-seeds and Jatropha under intercropping at Samaru, Nigeria

\begin{tabular}{l|r|l|l}
\hline $\begin{array}{l}\text { Legumes \& oilseeds } \\
\text { variety }\end{array}$ & $\begin{array}{l}\text { Grain yield (kg/ha) of } \\
\text { legumes \& oilseeds }\end{array}$ & $\begin{array}{l}\text { Days to maturity of } \\
\text { legumes \& oilseeds }\end{array}$ & $\begin{array}{l}\text { Jatropha capsule } \\
\text { yield (kg/ha) }\end{array}$ \\
\hline Cowpea & \multicolumn{5}{l}{} \\
\hline SAMPEA 6 & 6196 & 99 & 152 \\
\hline SAMPEA 7 & 274 & 92 & 166 \\
\hline SAMPEA 9 & 52 & 91 & 145 \\
\hline SAMPEA 10 & 1534 & 80 & 145 \\
\hline SAMPEA 11 & 11,117 & 97 & 128 \\
\hline SAMPEA 12 & 297 & 90 & 146 \\
\hline Groundnuts & \multicolumn{3}{l}{} \\
\hline SAMNUT 11 & 489 & 117 & 128 \\
\hline SAMNUT 14 & 239 & 87 & 159 \\
\hline SAMNUT 23 & 144 & 79 & 117 \\
\hline Soybeans & \multicolumn{3}{|l}{} \\
\hline TGX 1019-2E & 597 & 100 & 156 \\
\hline TGX 1835-10D & 308 & 121 & 150 \\
\hline TGX 1945-1F & 79 & 123 & 124 \\
\hline TGX 1904-6F & 25 & 132 & 143 \\
\hline
\end{tabular}

Source: Legumes and oil-seeds Research Programme Review Report of Institute for Agricultural Research, Ahmadu Bello University, Zaria (2012-2013) 
Table 3.3 Effect of nitrogen rates on performance of 2-year-old Jatropha curcas L. at Samaru

\begin{tabular}{l|l|l|l|l|l}
\hline $\begin{array}{l}\text { Nitrogen rates } \\
(\mathrm{N} / \mathrm{ha})\end{array}$ & $\begin{array}{l}\text { Plant } \\
\text { height }(\mathrm{cm})\end{array}$ & $\begin{array}{l}\text { Canopy } \\
\text { width }(\mathrm{cm})\end{array}$ & $\begin{array}{l}\text { 2010 Capsule } \\
\text { yield }(\mathrm{kg} / \mathrm{ha})\end{array}$ & $\begin{array}{l}\text { 2011 Capsule } \\
\text { yield }(\mathrm{kg} / \mathrm{ha})\end{array}$ & $\begin{array}{l}\text { Oil content } \\
(\%)\end{array}$ \\
\hline Zero & 38.2 & 46.2 & 36.0 & 126.4 & 37.6 \\
\hline 60 & 42.5 & 54.5 & 89.4 & 279.5 & 37.0 \\
\hline 120 & 38.4 & 52.5 & 50.7 & 343.2 & 36.6 \\
\hline 180 & 41.5 & 52.0 & 88.3 & 170.0 & 37.6 \\
\hline
\end{tabular}

seed viability therefore; seeds used for plantation purposes are kept at low temperature without losing viability and effective emergence. Seeds containing oil are properly stored and prepared for extraction to maintain high quality in the final product. Drying of seeds up to $4-8 \%$ moisture enhances storability and; higher moisture causes incidences of stored grain pests and diseases.

\subsubsection{Jatropha Cultivation and Soil Quality}

In SSA, Jatropha curcas L. cohabits with crops on farmers' fields; the shrub is planted as hedgerow plant to demarcate farm boundaries, protect high value crops from grazing goats, sheep and cattle herds and serve as wind breaks. The planted shrub in this instance, neither benefits from fertilizer nor pesticide application. Unlike the annual crops, Jatropha impact soil properties because of their large biomass accumulation, continuous and extensive root systems and longer residence time in soils (Sanchez et al. 1997). Jatropha hedgerow effect on soil quality indicators at five villages of the Sikasso region of Mali was studied by comparing soil properties beneath Jatropha with those of its companion crop in the agroforestry system; along with soils from an adjacent farm sown only to annuals. Results of the chemical properties evaluated, showed that Jatropha hedgerow slightly reduced soil $\mathrm{pH}$ beneath it, causing soils to range from slightly- to - moderately acid in reaction. Except for values at villages like Kani and Sirakele; the relative high soil organic carbon of the Jatropha hedgerow system compared to those of adjacent farm cropped to annuals (Table 3.4) is an indication of its contribution to decreasing atmospheric greenhouse gas emission as well as increasing soil fertility and quality.

Soils under Jatropha curcas could not outmatch those of companion crops and adjacent farms in total soil nitrogen content and available phosphorus (Table 3.4), probably due to the 'legacy' of fertilizer application on soils cropped to these annuals (cotton, maize, rice in that order) in Mali (Tappan and McGahuey 2007). It is, however, worth nothing that the shrub was able to reduce soil nutrients depletion, from the values obtained relative to those of the richly fertilized annuals and values of $\mathrm{Ca}^{2+}$ and $\mathrm{Mg}^{2+}$ were moderate to high in soils under Jatropha hedgerow systems than the soils cropped to annuals. When soil physical quality indicators were assessed, improvement in soil structural stability index caused by Jatropha (Table 3.5) affects positively the water storage capacity, porosity and soils resilience to erosion. Results of this study are in agreement with the inference of RuízValdiviezo et al. (2010) that marginal soils can be restored when planted with 
3 Promoting Jatropha Agriculture for Sustainable Soil Capital Improvement...

Table 3.4 Influence of Jatropha hedgerow systems as compared with adjacent soils on chemical properties of degraded soils in five villages of the Sikasso region in southern Mali

\begin{tabular}{|c|c|c|c|c|c|c|c|c|c|}
\hline Village & Practice & Texture & $\begin{array}{l}\text { Soil } \\
\text { pH }\end{array}$ & $\begin{array}{l}\text { Organic } \\
\text { carbon } \\
(\mathrm{g} / \mathrm{kg})\end{array}$ & $\begin{array}{l}\text { Total } \\
\text { nitrogen } \\
(\mathrm{g} / \mathrm{kg})\end{array}$ & $\begin{array}{l}\text { aAvail. } \\
\mathrm{P}(\mathrm{mg} / \\
\mathrm{kg})\end{array}$ & $\mathrm{Ca}^{2+}$ & $\mathrm{Mg}^{2+}$ & $\mathrm{K}^{+}$ \\
\hline \multirow[t]{2}{*}{ Kani } & $\begin{array}{l}\text { Beneath } \\
\text { Jatropha }\end{array}$ & $\begin{array}{l}\text { Sandy } \\
\text { loam }\end{array}$ & 5.1 & 3.2 & 0.07 & 8.4 & 3.7 & 0.5 & 0.09 \\
\hline & $\begin{array}{l}{ }^{\mathrm{b}} \text { Adjacent } \\
\mathrm{CBT} \text { maize } \\
\text { field }\end{array}$ & $\begin{array}{l}\text { Sandy } \\
\text { loam }\end{array}$ & 5.1 & 3.6 & 0.42 & 12.3 & 3.1 & 0.5 & 0.06 \\
\hline \multirow[t]{3}{*}{ Kani } & $\begin{array}{l}\text { Beneath } \\
\text { Jatropha }\end{array}$ & $\begin{array}{l}\text { Sandy } \\
\text { loam }\end{array}$ & 5.8 & 2.2 & 0.3 & 9.8 & 4.3 & 0.5 & 0.16 \\
\hline & $\begin{array}{l}\text { Companion } \\
\text { rice crop }\end{array}$ & $\begin{array}{l}\text { Silt } \\
\text { loam }\end{array}$ & 5.7 & 7.8 & 0.6 & 7.5 & 8.1 & 0.7 & 0.21 \\
\hline & $\begin{array}{l}\text { Adjacent } \\
\text { maize farm }\end{array}$ & Loam & 6.3 & 3.0 & 0.4 & 9.1 & 5.1 & 0.6 & 0.24 \\
\hline \multirow[t]{3}{*}{ Namposela } & $\begin{array}{l}\text { Beneath } \\
\text { Jatropha }\end{array}$ & $\begin{array}{l}\text { Sandy } \\
\text { loam }\end{array}$ & 5.7 & 6.0 & 0.6 & 6.0 & 2.1 & 0.6 & 0.13 \\
\hline & $\begin{array}{l}\text { Companion } \\
\text { sorghum }\end{array}$ & $\begin{array}{l}\text { Sandy } \\
\text { loam }\end{array}$ & 5.9 & 3.6 & 0.4 & 6.5 & 2.6 & 0.5 & 0.19 \\
\hline & $\begin{array}{l}\text { Adjacent } \\
\text { cotton farm }\end{array}$ & $\begin{array}{l}\text { Sandy } \\
\text { loam }\end{array}$ & 5.8 & 2.2 & 0.3 & 18.0 & 1.6 & 0.4 & 0.08 \\
\hline \multirow[t]{3}{*}{ Ngolonianasso } & $\begin{array}{l}\text { Beneath } \\
\text { Jatropha }\end{array}$ & $\begin{array}{l}\text { Sandy } \\
\text { loam }\end{array}$ & 6.0 & 15.0 & 0.8 & 12.0 & 13.3 & 0.6 & 0.27 \\
\hline & $\begin{array}{l}\text { Companion } \\
\text { rice crop }\end{array}$ & $\begin{array}{l}\text { Silt } \\
\text { loam }\end{array}$ & 6.0 & 17.0 & 0.8 & 83.0 & 15.4 & 0.7 & 0.19 \\
\hline & $\begin{array}{l}\text { Adjacent } \\
\text { maize farm }\end{array}$ & Loam & 5.2 & 6.0 & 0.4 & 4.0 & 7.7 & 0.6 & 0.52 \\
\hline \multirow[t]{3}{*}{ Ngolonianasso } & $\begin{array}{l}\text { Beneath } \\
\text { Jatropha }\end{array}$ & Loam & 5.5 & 1.2 & 0.07 & 6.8 & 2.1 & 0.5 & 0.4 \\
\hline & $\begin{array}{l}\text { Companion } \\
\text { rice crop }\end{array}$ & Loam & 5.9 & 1.0 & 0.07 & 8.4 & 3.9 & 0.6 & 0.7 \\
\hline & $\begin{array}{l}\text { Adjacent } \\
\text { groundnut } \\
\text { farm }\end{array}$ & $\begin{array}{l}\text { Sandy } \\
\text { loam }\end{array}$ & 5.9 & 1.8 & 0.14 & 9.5 & 3.9 & 0.5 & 0.4 \\
\hline \multirow[t]{3}{*}{ Sirakele } & $\begin{array}{l}\text { Beneath } \\
\text { Jatropha }\end{array}$ & $\begin{array}{l}\text { Sandy } \\
\text { loam }\end{array}$ & 6.1 & 3.2 & 0.21 & 5.8 & 2.5 & 0.5 & 0.3 \\
\hline & $\begin{array}{l}\text { Companion } \\
\text { cotton farm }\end{array}$ & $\begin{array}{l}\text { Sandy } \\
\text { loam }\end{array}$ & 6.4 & 2.4 & 0.14 & 4.9 & 2.6 & 0.5 & 0.1 \\
\hline & $\begin{array}{l}\text { Adjacent } \\
\text { sorghum } \\
\text { farm }\end{array}$ & Loam & 6.3 & 4.0 & 0.35 & 3.7 & 2.0 & 0.4 & 0.1 \\
\hline \multirow[t]{3}{*}{ Zanzoni } & $\begin{array}{l}\text { Beneath } \\
\text { Jatropha }\end{array}$ & $\begin{array}{l}\text { Sandy } \\
\text { loam }\end{array}$ & 6.3 & 5.6 & 0.3 & 48.5 & 6.6 & 0.6 & 0.3 \\
\hline & $\begin{array}{l}\text { Companion } \\
\text { rice crop }\end{array}$ & $\begin{array}{l}\text { Sandy } \\
\text { loam }\end{array}$ & 6.2 & 5.6 & 0.4 & 34.7 & 6.0 & 0.6 & 0.2 \\
\hline & $\begin{array}{l}\text { Adjacent } \\
\text { sorghum } \\
\text { farm }\end{array}$ & $\begin{array}{l}\text { Sandy } \\
\text { loam }\end{array}$ & 6.1 & 2.6 & 0.4 & 13.5 & 4.4 & 0.5 & 0.1 \\
\hline
\end{tabular}

${ }^{a}$ Available Phosphorus

${ }^{\mathrm{b}} \mathrm{CBT}$ - contour bund technology 
Table 3.5 Soil physical quality indicators as affected by Jatropha hedge-row system and soils of adjacent farms in Mali

\begin{tabular}{|c|c|c|c|c|c|}
\hline Village & Practice & $\begin{array}{l}\text { Air } \\
\text { Capacity } \\
\left(\mathrm{m}^{3} \mathrm{~m}^{-3}\right)\end{array}$ & $\begin{array}{l}\text { Plant available } \\
\text { water capacity } \\
\left(\mathrm{m}^{3} \mathrm{~m}^{-3}\right)\end{array}$ & $\begin{array}{l}\text { Soil structural } \\
\text { stability index } \\
(\%)\end{array}$ & $\begin{array}{l}\text { Relative } \\
\text { field } \\
\text { capacity }\end{array}$ \\
\hline \multirow[t]{2}{*}{ Kani } & $\begin{array}{l}\text { Beneath } \\
\text { Jatropha }\end{array}$ & 0.64 & 0.06 & 1.78 & 0.10 \\
\hline & $\begin{array}{l}\text { **Adjacent } \\
\text { CBT maize } \\
\text { field }\end{array}$ & 0.32 & 0.13 & 2.00 & 0.34 \\
\hline \multirow[t]{3}{*}{ Kani } & $\begin{array}{l}\text { Beneath } \\
\text { Jatropha }\end{array}$ & 0.33 & 0.06 & 0.93 & 0.31 \\
\hline & $\begin{array}{l}\text { Companion rice } \\
\text { crop }\end{array}$ & 0.28 & 0.12 & 2.21 & 0.45 \\
\hline & $\begin{array}{l}\text { Adjacent maize } \\
\text { farm }\end{array}$ & 0.35 & 0.08 & 1.20 & 0.33 \\
\hline \multirow[t]{3}{*}{ Namposela } & $\begin{array}{l}\text { Beneath } \\
\text { Jatropha }\end{array}$ & 0.36 & 0.10 & 2.96 & 0.24 \\
\hline & $\begin{array}{l}\text { Companion } \\
\text { sorghum }\end{array}$ & 0.41 & 0.05 & 2.48 & 0.16 \\
\hline & $\begin{array}{l}\text { Adjacent cotton } \\
\text { farm }\end{array}$ & 0.23 & 0.15 & 1.65 & 0.47 \\
\hline \multirow[t]{3}{*}{ Ngolonianasso } & $\begin{array}{l}\text { Beneath } \\
\text { Jatropha }\end{array}$ & 0.23 & 0.12 & 8.34 & 0.52 \\
\hline & $\begin{array}{l}\text { Companion rice } \\
\text { crop }\end{array}$ & 0.23 & 0.13 & 4.25 & 0.48 \\
\hline & $\begin{array}{l}\text { Adjacent maize } \\
\text { farm }\end{array}$ & 0.25 & 0.10 & 1.70 & 0.43 \\
\hline \multirow[t]{3}{*}{ Ngolonianasso } & $\begin{array}{l}\text { Beneath } \\
\text { Jatropha }\end{array}$ & 0.30 & 0.10 & 0.44 & 0.34 \\
\hline & $\begin{array}{l}\text { Companion rice } \\
\text { crop }\end{array}$ & 0.31 & 0.05 & 0.35 & 0.32 \\
\hline & $\begin{array}{l}\text { Adjacent } \\
\text { groundnut farm }\end{array}$ & 0.24 & 0.11 & 0.89 & 0.41 \\
\hline \multirow[t]{3}{*}{ Sirakele } & $\begin{array}{l}\text { Beneath } \\
\text { Jatropha }\end{array}$ & 0.37 & 0.02 & 1.13 & 0.141 \\
\hline & $\begin{array}{l}\text { Companion } \\
\text { cotton farm }\end{array}$ & 0.34 & 0.04 & 0.96 & 0.204 \\
\hline & $\begin{array}{l}\text { Adjacent maize } \\
\text { farm }\end{array}$ & 0.32 & 0.03 & 1.35 & 0.171 \\
\hline \multirow[t]{3}{*}{ Zanzoni } & $\begin{array}{l}\text { Beneath } \\
\text { Jatropha }\end{array}$ & 0.38 & 0.07 & 2.25 & 0.25 \\
\hline & $\begin{array}{l}\text { Companion rice } \\
\text { crop }\end{array}$ & 0.34 & 0.06 & 2.25 & 0.28 \\
\hline & $\begin{array}{l}\text { Adjacent } \\
\text { sorghum farm }\end{array}$ & 0.34 & 0.02 & 1.04 & 0.13 \\
\hline \multicolumn{2}{|l|}{${ }^{a}$ Optimal Range } & $\geq 0.15$ & $\geq 0.15$ & $>7$ & $0.6-0.7$ \\
\hline
\end{tabular}

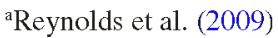


Jatropha due to the shrub's positive effect on the soil and the surrounding ecosystem. Now, within ecosystem assessment, degraded soils planted with Jatropha will resume with time to provide services such as supporting -(e.g. nutrients cycling, water retention, formation of soil and exchange of gases with the atmosphere, degradation of plants and other materials, etc), regulating - (water flow, water and air quality and sequestration of carbon from the atmosphere, emission of greenhouse gases, etc), cultural - (outdoor recreation, spiritual and religious interest, identity of landscapes, etc) services and; production of food, fuel and fibre that fall within the provisioning services of soils (Banwart et al. 2014).

\subsection{Analysis: Demystifying Jatropha curcas L.}

Global enthusiasm backed by a desire for profit that resulted in the establishment of failed mega plantation of Jatropha with multinationals such as D1 Oils, Viridas PLC and Energem Resources Inc., involved in the risky venture; has strengthened the need for reliable agronomic information to support agricultural decision making. Emerging agronomic results from experiments on Jatropha cultivation have shown that the shrub is not different from other cultivated oilseeds when it comes to managing soil, water, agrochemical etc. Observations on the occurrence of pests and diseases attacking Jatropha in 2010 at Samaru, Nigeria revealed that the shrub harbours more pests and diseases than previously assumed. For instance, termites (Microtermes spp and Odontotermes spp) attack that was hitherto rare on young Jatropha plants was found to be prevalent on newly open field planted to Jatropha; covering the lower portion of the plant with earth sheeting under which the green bark was progressively consumed and causing serious damage that resulted in wilted and breaking off branches. Piercing and sucking bugs notably, Anoplocnemis curvipes, Clavigralla tomentosicolis (Coreidae), Empoasca spp (Cicadelidae), Bemisia tabaci etc., are more frequently encountered in the plantations. A new pest, the inflorescence/capsule borer, Pempelia morasalis reported as Jatropha pest in India was observed in several locations in Nigeria on Jatropha, a new strain of begomovirus associated with mosaic disease of Jatropha causing blistering and mottling symptoms on the leaves was first identified in Nigeria and named Jatropha mosaic Nigeria virus (Kashina et al. 2012). Dieback disease, a foliage disease caused by the fungus- Fusarium $\mathrm{sp}$ - has been reported to be severe in Jatropha grown either in plantation or in the wild in Nigeria (Nasiru et al. 2015; Zarafi and Abdulkadir 2014).

\subsection{New Policy Directions for Jatropha Research}

There are many needs and actions that must be addressed for Jatropha curcas $\mathrm{L}$ (JCL) to be a win-win technology in soil improvement and land rehabilitation in SSA. First, using Jatropha, land rehabilitation will need to focus on a range of 
benefits and maximize synergies. Second, there is need to identify, through land assessment, degraded lands that can easily recover with Jatropha management. Third, reversing degradation trend with Jatropha needs high addition of organic matter in the form of Jatropha biomass; determination of organic carbon sequestration potential and the time-span for land recovery under Jatropha becomes crucial. Investments in Jatropha agronomic research, which incorporate ecosystem perspective and; modify and adapt Jatropha agricultural systems should be pursued across disciplinary boundaries. Without multidisciplinary cooperation among (at least) soil science, ecology, genetics, agronomy, economics and social sciences, and without engagement of stakeholders (particularly, farmers) in the effort, it is unlikely that we will be able to increase Jatropha yield while also protecting environmental quality and conserving natural resources. Information from research on genotype, environmental interaction and management is critical; socioeconomic research on market, institutions and pricing for $J C L$ and its byproducts be carried out. Fabrication of cheap, efficient seed pressing machines and cooking stoves that are powered by Jatropha oil is important, if rural utilization of $J C L$ is the goal.

\section{References}

Abdelgadir, HA, Jäger, AK, Johnson, SD, Van Staden, J, (2010) Influence of plant growth regulators on flowering, fruiting, seed oil content, and oil quality of Jatropha curcas. South African Journal of Botany 76: 440-446.

Achten, WMJ, Almeida, J, Fobelets, V et al (2010) Lifecycle assessment of Jatropha biodiesel as transportation fuel in rural India. Applied Energy 87: 3652-3660.

Banwart, S, Black, H, Cai, Z et al (2014) Benefits of soil carbon: report on the outcomes of an international scientific committee on problems of the environment rapid assessment workshop. Carbon Management 5 (2): 185-192.

Behera, SK, Srivastava, P, Tripathi, R et al (2010) Evaluation of plant performance of Jatropha curcas $L$. under different agricultural practices for optimizing biomass- a case study. Biomass and Bioenergy 34: $30-41$

Bekunda, M, Palm, CA, de Fraiture, C et al (2009) Biofuels in developing countries. In Howarth, $\mathrm{RW}$, Bringezu, S (eds) Biofuels: environmental consequences and interactions with changing land use. Proceedings of the Scientific Committee on Problems of the Environment (SCOPE) International Biofuel Project Rapid Assessment, 22-25 September 2008, Gummersbach Germany. Cornell University, Ithaca NY, USA. (http://cip.cornell.edu/biofuel). 249-269

Biswas, P.K., Pohit, S. \& Kumar, R, (2010) Biodiesel from Jatropha: Can India meet the $20 \%$ blending target? Energy Policy 38: 1477-1484.

Burley, H, Griffiths, H, (2009) Jatropha: wonder crop? Experience from Swaziland. Friends of the Earth Publication

Bustamante, MMC, Melillo, J, Connor, DJ et al. (2008) In Howarth, RW, Bringezu, S (eds) Biofuels: environmental consequences and interactions with changing land use. Proceedings of the Scientific Committee on Problems of the Environment (SCOPE) International Biofuel Project Rapid Assessment, 22-25 September 2008, Gummersbach Germany. Cornell University, Ithaca NY, USA. (http://cip.cornell.edu/biofuel), 265-285

Craswell, ET, Lefrog, RDB, (2001) The role and function of organic matter in tropical soil. Nutrient Cycling in Agroecosystems 61: 7-18.

FAO (Food and Agriculture Organization) (2006) World Agriculture: towards 2030-2050. Food and Agriculture Organization of the United Nations, Rome. 
Ghosh, A, Chaudhary, DR, Reddy, MP et al (2007) Prospects of Jatropha methyl ester (biodiesel) in India. International Journal of Environmental Studies 64: 659-674

Ghosh, A, Chikara, J, Chaudhary, DR (2011) Diminution of economic yield as affected by pruning and chemical manipulation of Jatropha curcas L. Biomass and Bioenergy 35: 1021-1029.

Godfray, HCJ, Beddington, JR, Crute, IR et al (2010) Food security: the challenge of feeding 9 billion people. Science 327: 812-818.

Halilu, AD, Misari, SM, Echekwe, CA et al (2011) Survey and collection of Jatropha curcas L. in the northwestern Savannas of Nigeria. Biomass and Bioenergy 35: 4145-4148.

Jain, S, Sharma, MP (2010) Prospects of biodiesel from Jatropha in India: a review. Renewable and Sustainable Energy Reviews 14: 763-771.

Kashina, BD, Alegbejo, MD, Banwo, OO, Nielsen, SL, Nicolaisen, M (2012) Molecular identification of a new begomovirus associated with mosaic disease of Jatropha curcas L in Nigeria. Arch Virol. https://doi.org/10.1007/s00705-012-1512-7.

Lal, R., (2004) Soil carbon sequestration impacts on global climate change and food security. Science 304: 1623-1627.

Mittlelbach, M, (1996) Diesel fuel from vegetable oil. Bioresource Technology 27: 35-43.

Montanarella, L, Alva, IL (2015) Putting soils on the agenda: the three Rio conventions and the post-2015 development agenda. Current Opinion in Environmental Sustainability 15: 41-48.

Nasiru, AM., Banwo, OO, Isah, AD, Zarafi, AB (2015) Identification and pathogenicity of fusarium and phomopsis foliar diseases of Jatropha curcas L in northwest states of Nigeria. World Research Journal of Agricultural Sciences 2: 22-27.

Ogunwole, JO (2014) Development of commercially viable plantations of Jatropha curcas L: case for promotion of its agricultural research. Advances in Plants \& Agriculture Research $I$ (3): 00017. http://dx.doi.org/apar.2014.01.00017.

Ogunwole, JO (2009) Managing Africa's Natural Resources to Mitigate Land Degradation: A Soil Science Perspective. Agrarian Science for Sustainable Resource Management in Sub-Saharan Africa, Studies in sub-Saharan Africa Vol. 3. ISBN 978-3-631-58524-5.

Ogunwole, JO, Chaudhary, DR, Ghosh, A et al (2008) Contribution of Jatropha curcas to soil quality improvement in a degraded Indian entisol. Acta Agriculturae Scandinavica, Section B-Plant Soil Science 58:245-251

Peskett, L, Slater, R., Stevens, C, Dufey, A (2007) Biofuels, agriculture and poverty reduction Overseas Development Institute 107: 1-6.

Reynolds, WD, Drury, CF, Tan, CS et al (2009) Use of indicators and pore volume-functions characteristics to quantify soil physical quality. Geoderma 152: 215-225.

Sahoo, NK, Kumar, A, Sharma, S, Naik, SN (2009) Interaction of Jatropha curcas plantation with ecosystem. Proceedings of International Conference on energy and environment. EnviroEnergy, March 19-21. ISSN: 2070-3740, 666-671

Scherr, SJ, Yadav, S, (1996) Land degradation in the developing world: implications for food, agriculture, and environment to 2020. Food, Agriculture and the Environment Discussion Paper 14. International Food Policy Research Institute, New York: USA.

Sieg, K, (2006) Flowers in the desert. In: New Energy (Magazine for Renewable Energy) 5: 54-57. Berlin Germany.

Stocking, MA, (2003) Tropical soils and food security: the next 50 years. Science 302:1356-1359

Tilman, D, Socolow, R, Foley, J et al (2009) Beneficial biofuels-the food, energy, and environment trilemma. Science 325: 270-271.

Tappan, G, McGahuey, M (2007) Tracking environmental dynamics and agricultural intensification in southern Mali. Agricultural Systems 94: 38-51.

UN (United Nations) (2003) World population prospects-the 2002 revision, United Nations, New York.

UNCCD (1994) United Nations Convention to combat Desertification in those countries experiencing serious drought and/or desertification, particularly in Africa-final text of the convention, UNCCD, Bonn.

UNEP (2012) The benefits of soil carbon. In: The United National Environment Programme (UNEP) Yearbook 2012.UNEP, Nairobi, Kenya. 


\title{
Chapter 4 \\ Climate Change and Rapidly Evolving Pests and Diseases in Southern Africa
}

\author{
Paramu Mafongoya, Augustine Gubba, Vaneson Moodley, Debra Chapoto, \\ Lavinia Kisten, and Mutondwa Phophi
}

\begin{abstract}
Agriculture faces the huge challenge of meeting increasing food demands while simultaneously reducing its environmental footprint and meeting sustainability goals. Climate change is a major risk to sub-Saharan Africa and the southern Africa region. Pests are, and will continue to be responsible for crop losses which may amount to more than $40 \%$ worldwide. Climate change and weather patterns directly affect the distribution, development and population dynamics of insect pests and it may facilitate the spread of indigenous and exotic species. The aim of the study was to identify and evaluate major pests of vegetables in South Africa and Zimbabwe in relation to climate variability. Quantitative and qualitative research methods were used to solicit data from respondents. This was done across all nine provinces of South Africa and five agro-ecological zones in Zimbabwe. Key informants and focus groups were used to triangulate the data. Whiteflies and aphids collected from field and greenhouse sampling sites were phenotyped to determine the possible species present. In Zimbabwe, farmers perceived an increase in the abundance of insect pests such as aphids, whiteflies, stem borers, ball worms, red spider mite, termites and diamondback moths and the emergence of new pests. The increase in pest populations was perceived to be caused by short winters, higher temperatures and lengthy dry spells. In South Africa, the major pest outbreaks were aphids, whiteflies, red spider mites and thrips. Moreover, some of these pests are vectors of destructive viral pathogens. Emerging whitefly-transmitted torrado, crini, and begomoviruses were identified in major vegetable growing regions throughout South Africa. From this study, Tomato torrado virus (ToTV) was reported for the first time from continental Africa continent. In addition, several weed species significantly contributed to the epidemiology of vector-borne disease in commercial and smallholder farming communities. Preliminary risk maps for possible pest and disease outbreaks were produced for the two countries. The major policy directions require governments in Africa to start documenting new and emerging pests and diseases of major crops. Furthermore, surveillance systems should be initiated to
\end{abstract}

P. Mafongoya (四) $\cdot$ A. Gubba $\cdot$ V. Moodley $\cdot$ D. Chapoto $\cdot$ L. Kisten $\cdot$ M. Phophi School of Agriculture, Earth and Environmental Science, University of Kwa Zulu Natal, Pietermaritzburg, South Africa 
monitor pest populations and extension programs that create awareness to farmers on new and existing pests and how to manage them. A collaborative effort is paramount for the development of appropriate integrated pest management systems to reduce the losses incurred by the agricultural pests in Africa and abroad.

Keywords Climate change $\cdot$ Diseases $\cdot$ Pests $\cdot$ South Africa $\cdot$ Zimbabwe $\cdot$ Sustainability

\subsection{Introduction}

The twenty-first century began with a twofold challenge of meeting food demands and satisfying sustainability goals. The incidence of emerging, new, and more aggressive pests (insects, pathogens, and weeds) affecting yield levels and stability, thereby threatening food security, has increased over the past number of years. Climate change in addition to anthropogenic impacts will certainly impact the distribution and severity of pest incidence. This is because it is not possible to make simple and sweeping assumptions regarding the potential overall losses and certain pests adapt unpredictably to a changing environment. In Southern Africa, the diamondback moth caterpillar and whiteflies caused near total crop loss on cabbages (Katsaruware-Chapoto et al. 2017). Tomatoes infested with the invasive leaf miner Tuta absoluta affect the commercial value of tomatoes in Southern Africa. In the absence of effective control measures, it causes losses of 50-100\% (KatsaruwareChapoto et al. 2017)

Pests are, and will continue to be, responsible for crop losses which amount to more than $40 \%$ worldwide (Oerke 2006). The reduction of their impacts is more relevant than ever, not only to produce enough food and commodities but also to reduce excess input use and unnecessary $\mathrm{CO}_{2}$ emissions. Mitigation and adaptation strategies are therefore needed to reduce the impacts of new pests as well as existing ones in plant production systems. The main consequence of climate change and accelerated globalization is a heightened level of unpredictability regarding spatial and temporal interactions between weather, cropping systems, and pests. $A$ wider range of insect pests, pathogens and weeds may be affected by climate change. Climate change is generally associated with increased $\mathrm{CO}_{2}$ level, high seasonal temperature, and erratic rainfall patterns. These global changes will affect the distribution and severity of pests; however, whether such changes will cause more outbreaks cannot be answered in general terms.

Climate and weather patterns are of primary importance for the distribution, development, and population dynamics of insects relative to their ectothermic nature. Insect physiology is primarily driven by temperature which means the phenology, reproduction and development rate changes are expected to increase when exposed to other climate regimes. Climate thresholds and day length largely determine the potential distribution of insect species when host plants are available. On the other hand, insects are constantly adapting their life history patterns to available regimes or season lengths. Due to their developments, evolutionary adaptations to 
life cycles occur in a very short period, so the on-going climatic changes will certainly lead to increased outbreaks (IPCC 2007).

In terms of phenological changes, the earlier onset and increased length of the growing season means that indigenous polyvoltine species may be able to complete more generations per year leading to higher populations at the end of the season. Besides higher population pressure, the potential damage is expected to last longer within the growing seasons and crops must be protected. Knowledge about pest biology and potential adaptation of insect pests to climate change is necessary and needs to be combined with surveillance studies in order to prepare management systems that can withstand a changing global climate. Shifts in phenology due to changing temperature may also cause the synchrony between host plants, pest species, and natural enemies. Higher temperatures during the growing season and higher winter temperatures are very significant in the distribution of many insect species. Some species can skip their sexual reproduction and have new asexual generations throughout the year, which may lead to high population levels. Many studies have shown that aphids have shifted from holocyclic (primary and secondary hosts) to anholocyclic (only secondary host i.e. only crop plants). These processes are likely to have an impact on crops and increase pest management costs. If increased temperature will allow aphids to remain on the secondary host (crop and non-crop species) it allows rapid colonization of crops early in the season. Higher temperatures will allow insects population to colonize crops earlier and develop faster. In this manner, crop damage will occur more rapidly than currently observed. In addition, new emerging species often spread in completely new ecological settings where most of their natural enemies are absent. A case in point is the introduction of B-biotype (Bemisia tabaci in Brazil) which was responsible for vectoring viruses present in natural plants only onto cultivated tomato crops and leading to new virus diseases in these crops (Fernandes et al. 2008).

Knowledge on the effect of climate change on exotic pest's incursions and globalization on crop protection pose a higher level of unpredictability regarding future crop-pest-climate interaction and increased frequency and amplitude of climatic fluctuations. It can be concluded that there will be an acceleration in the rate of exotic pest's entry and establishment in Africa as well as the accelerated rate of evolution of existing pest populations. Hence the need to develop integrated pest management strategies that are dynamic and internally diversified to locally adapted cropping systems which are more resilient to fluctuating weather conditions and new and evolving pests.

Weeds are often inconspicuous threats in agriculture, which evolve in response to agricultural management practices. Climate change is likely to exacerbate weed infestations and distribution as environmental conditions become more favorable (Padalia et al. 2015). Increasing temperatures allow plants to complete their lifecycle quicker resulting in weeds inhabiting previously uninhabited areas, consequently extending their geographic range (Clements et al. 2014). Most of the world's problematic weeds are $\mathrm{C}_{4}$ plants (Clements et al. 2014). $\mathrm{C}_{4}$ plants can 
photosynthesize more efficiently than $\mathrm{C}_{3}$ plants at higher temperatures (Peters et al. 2014). Consequently, these weeds may thrive as a result of elevated temperatures. Weeds also have the advantage of being more adept at utilizing $\mathrm{CO}_{2}$ (Clements et al. 2014). Weeds are important components in cropping systems either by acting as a pest itself or by harboring vectors and vector-borne diseases (Van Bogaert et al. 2015). Weeds inhibit crop growth by outcompeting crops for essential nutrients, space, and water (Goyal et al. 2015). Furthermore, weeds play a critical role in the incidence and spread of vector-borne disease in agricultural systems throughout the world (Prajapat et al. 2014). They serve as potential sources of primary viral inoculum of both known and unidentified virus species (Asala et al. 2014). Furthermore, viruses can overwinter on weeds in the absence of crop hosts, allowing for their continued survival between cropping seasons (Kwon et al. 2016)

Therefore, this study aimed to identify and evaluate major pests of vegetables in South Africa and Zimbabwe in relation to climate variability. The second objective was to determine farmer's perspectives on new and emerging pests and their control measures

\subsection{Materials and Methods}

\subsubsection{Data Collection}

A countrywide survey of pests and disease was conducted in the major vegetable growing areas of South Africa and five agro-ecological regions in Zimbabwe during the 2014-2016 growing season. The climatic conditions across South Africa's nine provinces (generally ranging from Mediterranean in the southwest to temperate in the interior highland, and subtropical in the northeast) are more variable than in other countries in sub-Saharan Africa. Zimbabwe's five agro-ecological areas otherwise known as natural regions are characterized by soil types, temperature and rainfall patterns (Table 4.1).

All collections were authorized by the Department of Agriculture, Forestry and Fisheries (South Africa), government extension workers and landowners of private property. Vegetable crops belonging to the families Solanaceae, Cucurbitaceae, Brassicaceae, Amaryllidaceae, and Fabaceae were screened for aphids, thrips, and whiteflies. Infested crops and nearby weeds from fields and greenhouses exhibiting virus-like symptoms were collected and transported on dry ice for further analysis. Aphid and whitefly vectors were randomly collected from the top and undersurface of symptomatic leaf tissue and preserved in $95 \%$ ethanol. Samples were labeled according to GPS coordinates/altitude, crop cultivation, type of vector, infestation levels (low; medium; high) and to symptomatology. 
Table 4.1 The five agro-ecological regions in Zimbabwe

\begin{tabular}{|c|c|c|c|c|c|c|}
\hline Natural region & Latitude & Longitude & Altitude & Mean $\mathrm{T}^{\circ} \mathrm{C}$ & Mean $\mathrm{T}^{\circ} \mathrm{C}$ & Mean \\
\hline (District) & ${ }^{\circ} \mathrm{S}$ & ${ }^{\circ} \mathrm{E}$ & (m) & (Max) & (Min) & Rainfall (mm) \\
\hline \multirow[t]{2}{*}{1 (Chipinge) } & 20.1 & 32.4 & 1522 & $11-12$ & 23 & $>1000$ \\
\hline & 19.8 & 32.7 & 1500 & & & \\
\hline \multirow[t]{2}{*}{2 (Goromonzi) } & 17.4 & 31 & 1500 & $10-13$ & 23 & $750-1000$ \\
\hline & 17.3 & 31.1 & 1537 & & & \\
\hline \multirow[t]{2}{*}{3 (Mutoko) } & 18.3 & 29.9 & 1156 & $11-15$ & 26 & $650-750$ \\
\hline & 17.2 & 32.1 & 1160 & & & \\
\hline \multirow[t]{2}{*}{4 (Musvingo) } & 19.5 & 30.5 & 1129 & $11-18$ & 28 & $450-650$ \\
\hline & 19.4 & 29.6 & 1203 & & & \\
\hline \multirow[t]{2}{*}{5 (Chiredzi) } & 20.4 & 32.3 & 438 & $14-20$ & 32 & $<450$ \\
\hline & 21.7 & 31.4 & 532 & & & \\
\hline
\end{tabular}

Notes: Geographic coordinates indicates the general area where the study was conducted. In Parentheses are the districts in which the study was undertaken. Min refers to minimum, Max refers to maximum, $\mathrm{T}^{\circ} \mathrm{C}$ refers to temperature, and $\mathrm{m}$ refers to meters

\subsubsection{Molecular Assays}

Total RNA and total DNA was extracted from more than 130 plant tissue samples collected from various sampling points in South Africa using a Quick-RNA ${ }^{\mathrm{TM}}$ MiniPrep Kit (Zymo Research, USA) and Quick-DNA ${ }^{\text {TM }}$ Universal Kit (Zymo Research, USA), respectively according to manufacturers' instructions. The transcription of RNA to DNA was performed using Revert Aid premium first strand cDNA Kit (Thermo Scientific, USA) following the manufacturers' guidelines. A gene-specific primer was used for cDNA synthesis of viruses belonging to the potyvirus, torradovirus, ipomovirus, carlavirus, crinivirus, and tospovirus groups (Table 4.2). Poty and ipomo viruses belong to the same family of viruses; hence a universal potyviridae primer was used. Each reverse transcription (RT) reaction was carried out in $20 \mu \mathrm{l}$ volumes incubated at $42{ }^{\circ} \mathrm{C}$ for $1 \mathrm{~h}$ followed by an enzyme termination step at $70^{\circ} \mathrm{C}$ for $5 \mathrm{~min}$ using a G-Storm thermocycler.

Universal begomovirus primers were used to test for DNA viruses (Table 4.1). All viruses were initially detected using polymerase chain reaction (PCR). PCR was carried out in $20 \mu \mathrm{l}$ volumes using KAPA 2G Universal Master Mix (Kapa Biosystems, South Africa). Each reaction contained $3 \mu \mathrm{l}$ of DNA, $10 \mu \mathrm{M}$ of each primer and $10 \mu \mathrm{l}$ of KAPA master mix. Conditions for PCR were $95^{\circ} \mathrm{C}$ for $2 \mathrm{~min}$ followed by 35 cycles of $95^{\circ} \mathrm{C}$ for $30 \mathrm{~s}, 47^{\circ} \mathrm{C}-56^{\circ} \mathrm{C}$ for $35 \mathrm{~s}$ (depending on primer pair annealing temperature in Table 4.1) and $72^{\circ} \mathrm{C}$ for $30 \mathrm{~s}$ with a final elongation step of $72{ }^{\circ} \mathrm{C}$ for $10 \mathrm{~min}$. All positive samples were cloned using a TA cloning kit (Invitrogen, California, USA) and sequenced in both directions using Sanger sequencing at Inqaba biotechnological industries (Pretoria, South Africa). Sequences were aligned and analyzed using MEGA 6.06 software (Tamura et al. 2013). 
Table 4.2 Primers used to detect different vector-borne viruses based on typical virus-like symptoms

\begin{tabular}{|c|c|c|c|c|c|c|}
\hline Virus & Primers & Sequence $5^{\prime}-3^{\prime}$ & Amplicon & $\mathrm{T}_{(\mathrm{A})}$ & Target & Source \\
\hline \multirow[t]{2}{*}{ Begomovirus } & TY $1(+)$ & GCCCATGTA(T/C)-CG(A/G)AAGCC & $580 \mathrm{bp}$ & $50^{\circ} \mathrm{C}$ & Coat protein & \multirow[t]{2}{*}{ Accotto et al. (2000) } \\
\hline & TY2(-) & $\begin{array}{l}\text { GG(A/G)TTAGA(A/G)GCATG(A/C) } \\
\text { GTAC }\end{array}$ & & & & \\
\hline \multirow[t]{4}{*}{ Crinivirus } & $\begin{array}{l}\text { Solanaceae } \\
(\mathrm{R})\end{array}$ & GTGTTBGAYAACCAWGTGTT & & $52^{\circ} \mathrm{C}$ & \multirow[t]{4}{*}{$\begin{array}{l}\text { RNA-dependent RNA } \\
\text { polymerase }\end{array}$} & \multirow[t]{4}{*}{$\begin{array}{l}\text { Wintermantel and Hladky } \\
\text { (2010) }\end{array}$} \\
\hline & $\operatorname{TICV}(\mathrm{F})$ & AAGAATGGACCTACCCAG & $995 \mathrm{bp}$ & & & \\
\hline & ToCV (F) & GCACCCTGATTGGTTCTAAAC & $265 \mathrm{bp}$ & & & \\
\hline & PYVV (F) & ATCGTTCGTTCTCAACCG & $514 \mathrm{bp}$ & & & \\
\hline \multirow[t]{3}{*}{ Potyviridae } & M4T (R) & GTT TTCCCAGTCACGAC(T) $)_{15}$ & $1700 \mathrm{bp}$ & $47^{\circ} \mathrm{C}$ & \multirow[t]{3}{*}{ Nuclear inclusion body b } & \multirow[t]{3}{*}{ Chen et al. (2001) } \\
\hline & S-primer & GGXAAYAAYAGYGGXCAZCC & & & & \\
\hline & $\mathrm{M} 4^{\mathrm{b}}$ & GTTTTC CCAGTCACGAC & & & & \\
\hline \multirow{2}{*}{$\begin{array}{l}\text { Potato virus } \\
\text { Y }\end{array}$} & VPg-R & GCTTCATGYTCYACHTCCTG & $547 \mathrm{bp}$ & $56^{\circ} \mathrm{C}$ & \multirow[t]{2}{*}{ Viral genome-linked protein } & \multirow[t]{2}{*}{ Khalifa et al. (2009) } \\
\hline & VPg-F & GAATYCAAGCHYTRAAGTTTCG & & & & \\
\hline \multirow[t]{4}{*}{ Torradovirus } & Torrado-1R & GGWACWGCMACHAGRTTGTCATC & $371 \mathrm{bp}$ & $52^{\circ} \mathrm{C}$ & \multirow{2}{*}{$\begin{array}{l}\text { RNA-dependent RNA } \\
\text { polymerase }\end{array}$} & \multirow[t]{2}{*}{ Verbeek et al. (2012) } \\
\hline & Torrado-1F & GCWGAYTAYTCMAGYTTTGATGG & & & & \\
\hline & Torrado-2R & CCWGTCCACCAYTTGCAATT & $515 \mathrm{bp}$ & $52^{\circ} \mathrm{C}$ & \multirow{2}{*}{$\begin{array}{l}\text { Coat proteins Vp35 and } \\
\text { Vp26 }\end{array}$} & \multirow[t]{2}{*}{ Verbeek et al. (2012) } \\
\hline & Torrado-2F & TGGGATGARTGYAATGTKCT & & & & \\
\hline \multirow[t]{2}{*}{ Tospovirus } & gM870c (R) & ATTAGYTTGCAKGCTTCAATNAARGC & $500 \mathrm{bp}$ & $52^{\circ} \mathrm{C}$ & \multirow{2}{*}{$\begin{array}{l}\text { Non-structural protein on } \mathrm{M} \\
\text { strand }\end{array}$} & \multirow[t]{2}{*}{ Chen et al. (2012) } \\
\hline & gM410 (F) & AACTGGAAAAATGATTYNYTTGTTGG & & & & \\
\hline
\end{tabular}

${ }^{\mathrm{a}} \mathrm{T}_{(\mathrm{A})}-$ Annealing temperature 


\subsubsection{Serology}

Enzyme-linked immunosorbent assay (ELISA) was used to identify and differentiate strains of some viruses detected in this study. Samples were analyzed using a FLUOstar OPTIMA microplate reader (BMG Labtech, Ortenberg, Germany). Absorbance values were recorded at $405 \mathrm{~nm}$. All samples with twice the absorbance value of the negative control were considered virus positive.

\subsubsection{Survey Data Collection Procedure}

Quantitative and qualitative research approaches were used in the study. Quantitative information was collected from the farmers through a survey questionnaire. In the first and second stages, farmers were subjectively (purposively) sampled from the five natural regions (NR) of the country (Table 4.1). Two wards in each NR composed of smallholder farmers (with a landholding of less than $6 \mathrm{ha}$ ) were sampled based on lists of farmers and intensity of crop production activities as perceived by the District Agriculture Extension (AGRITEX) Officer. From each ward, 5 villages were then sampled based on the same criteria. Five farmers from each village were then randomly selected from each village for the purpose of this study resulting in 50 respondents in each agro-ecological region.

\subsection{Data Analysis}

Data analysis was initially carried out by coding household survey data in Microsoft Excel. The data was then transferred to SPSS package for statistical data analysis. The data was then subjected to analysis of variance. Significance was accepted at $\mathrm{p}<0.05$. In cases where significant differences were found, a Post Hoc analysis was conducted to determine the NR which showed significant differences. Frequencies, percentages, and problem ranking matrices were also used in the study to generate summaries and tables.

\subsection{Results}

\subsubsection{Assessment of Vegetable Growing Regions}

Insect pests and particularly vectors such as whiteflies and aphids were widely distributed throughout South Africa and Zimbabwe. Thrips were not as abundant in South Africa as in many tomato-growing areas in Zimbabwe. Infestation levels 
varied according to location, open field and greenhouse cultivation (Fig. 6.1, frame G). Mosaic, mottling, chlorosis and necrosis were some of the symptoms observed on various crops and nearby weed species inhabited by varying levels of vector populations (Fig, 4.1).

Phenotypic screening of whitefly vectors showed that Bemisia sp. and Trialeurodes sp. were present in both countries. Western flower thrips Frankliniella occidentalis (Pergande) and onion thrips Thrips tabaci (Lindeman) were identified to a lesser extent in the eastern regions and more concentrated in the north and northwestern parts of South Africa.
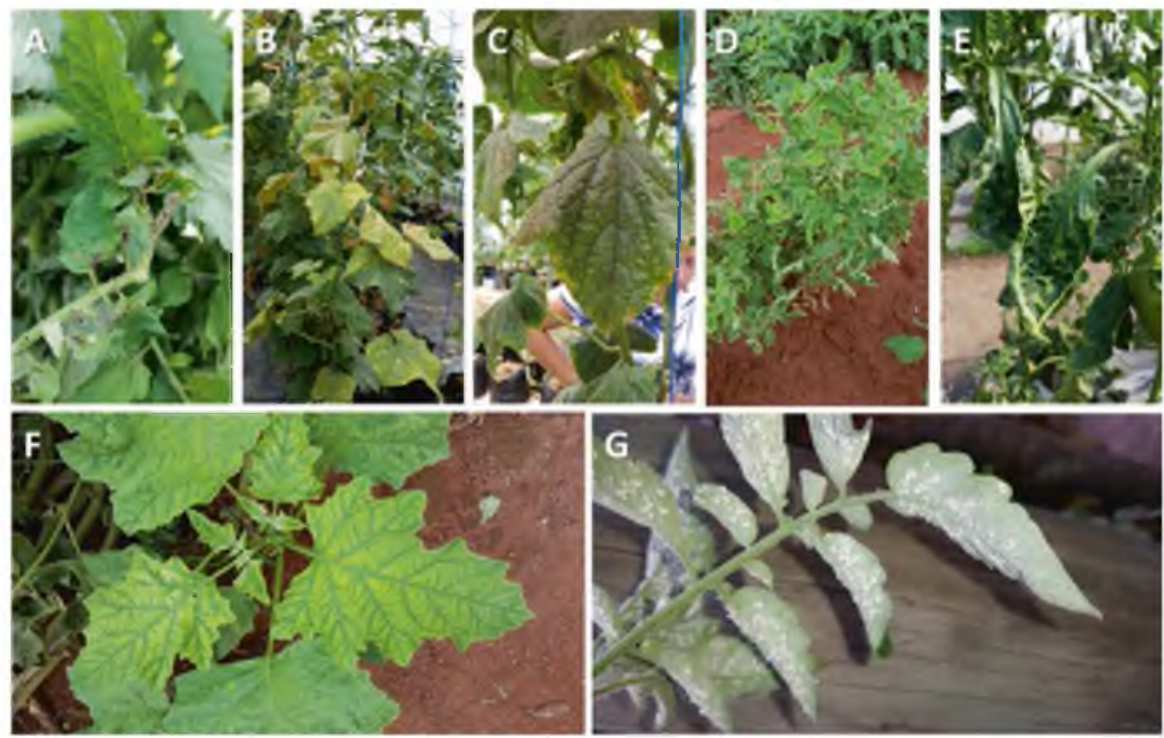

Fig. 4.1 Typical virus-like symptoms observed on vegetable crops and weeds infested with varying levels of vector populations. (A) Necrotic spots at the base of tomato leaves surrounded by chlorotic halos and vertical necrosis on stems typically associated with Tomato torrado virus (ToTV) spread by whiteflies. (B) Interveinal chlorosis on which begins on leaves at the base of cucumber gradually moving upwards are usually signs of infection by whitefly-transmitted criniviruses. (C) A fungus known as sooty mold that grows on the surface of leaves as a result of honeydew secreted by whiteflies during feeding. The fungus impedes photosynthetic activity of the plant. (D) Severe stunting and upward leaf curling which results from infection of whiteflytransmitted begomoviruses, a highly destructive group of DNA viruses with geminate type particles. (E) Greenhouse cultivates peppers displaying stunting, mottling and upward leaf curl following outbreaks of aphids and whiteflies. Symptom severity is enhanced by mixed infections of viruses resulting in viral-synergism. Total crop loss is usually the outcome of such circumstances. (F) Nearby and adjacent broadleaf weed species such as Datura stramonium abundantly populate greenhouses and fields. Interveinal chlorosis symptoms suggest the possibility of criniviruses since large whitefly populations were observed on the abaxial leaf surface. (G) An example of high vector infestation levels observed in a commercial greenhouse facility in Hopefield Western Cape, South Africa. Pest pressure of this magnitude significantly reduces plant turgidity which eventually overwhelms the plant 
In Zimbabwe, high populations of $F$. occidentalis were identified in natural region 2 spanning a $40 \mathrm{~km}$ radius of Harare's central business district. These are areas in which tomatoes are grown extensively. T. tabaci was the predominant vector on alliums particularly on onions cultivated throughout the counties five natural regions. High infestation levels of the winged green peach aphid Myzus persicae (Sulzer) were observed early in the growing season throughout much of South Africa's major vegetable producing areas. Non-winged forms persisted throughout the summer. In Zimbabwe, natural region 2 had excessively high aphid populations in comparison to other regions in the country. Interestingly, natural region 2 and 4 only experienced major aphid outbreaks during the winter.

Most farms surveyed in South Africa and Zimbabwe were infested with a myriad of weed species that were colonized by large populations of insect pests and disease vectors that exhibited virus-related symptoms among other physiological disorders (Fig. 4.1, Frame F). Broadleaf weeds were the most abundant species growing among rows of crops and surrounding areas which many farmers seemed to neglect. The extent of weed species in some greenhouses and fields indicated their ability to thrive under poor management practices and ideal environmental conditions.

\subsection{Molecular and Sequence Analysis}

RT-PCR (Reverse Transcription Polymerase Chain Reaction) and PCR (Polymerase Chain Reaction) were used to detect possible vector-borne viruses based on host symptomatology. The use of universal and specific primers indicated some of the major vector-borne viruses damaging vegetable crops in South Africa and Zimbabwe. Although insect pests such as whiteflies, aphids, and thrips directly damage crops through feeding, it is their role as vectors of viruses that produce the highest economic losses. Therefore, pest populations were assessed together with host symptomatology. Viruses belonging to the Potyviridae [ssRNA (+)], Bunyaviridae [ssRNA (-)], Secoviridae [ssRNA (+)], Closteroviridae [ssRNA (+)] and Geminiviridae [ssDNA] groups were identified thus far. BLAST analysis confirmed the sequence identity of the virus species detected to date (Table 4.3). Much of the viral symptoms causing devastating effects to the vegetable crops surveyed in both countries remain to be characterized.

\subsubsection{Enzyme-Linked Immunosorbent Assay}

Potato virus $\mathrm{Y}(\mathrm{PVY})$ is divided into three main strain groups i.e. $\mathrm{PVY} \mathrm{O}^{\mathrm{O}}, \mathrm{PVY}^{\mathrm{C}}$, and $P V Y^{\mathrm{N}}$. These parental strains occur less frequently as a result of genetic recombination. All PVY isolates infecting pepper, tomato, and the solanaceous weed A. thunbergii reacted positively with O-type antibodies. Sequence analysis of the $550 \mathrm{bp}$ virus genome-linked protein ( $\mathrm{VPg}$ ) and the $1.7 \mathrm{~Kb}$ fragment flanking the 3'NTR 
Table 4.3 Identification of vector-borne virus species infecting vegetable crops and weeds in South Africa and Zimbabwe

\begin{tabular}{|c|c|c|c|c|c|}
\hline Area & $\begin{array}{l}\text { Virus } \\
\text { species }\end{array}$ & Host species & $\begin{array}{l}\text { Identity } \\
\text { match }\end{array}$ & $\begin{array}{l}\text { Accession } \\
\text { No. }\end{array}$ & Reference \\
\hline $\begin{array}{l}\text { South } \\
\text { Africa }\end{array}$ & ToTV & S. lycopersicum ${ }^{\mathrm{a}}$ & $99 \%$ & KP890356 & Moodley et al. (2016a) \\
\hline $\begin{array}{l}\text { South } \\
\text { Africa }\end{array}$ & ToTV & D. straminium ${ }^{b}$ & $99 \%$ & KP890356 & Moodley et al. (2016a) \\
\hline $\begin{array}{l}\text { South } \\
\text { Africa }\end{array}$ & ToCV & S. lycopersicum ${ }^{\mathrm{a}}$ & $98 \%$ & KT989862 & Moodley et al. (2016b) \\
\hline $\begin{array}{l}\text { South } \\
\text { Africa }\end{array}$ & ToCV & D. straminium ${ }^{\mathrm{b}}$ & $98 \%$ & KT989862 & Moodley et al. (2016b) \\
\hline $\begin{array}{l}\text { South } \\
\text { Africa }\end{array}$ & TSWV & A. thunbergit ${ }^{\mathrm{b}}$ & $91 \%$ & KU975371 & Kisten et al. (2016a) \\
\hline $\begin{array}{l}\text { South } \\
\text { Africa }\end{array}$ & TSWV & S. lycopersicum ${ }^{\mathrm{a}}$ & $91 \%$ & KY039275 & Kisten et al. (2016a) \\
\hline $\begin{array}{l}\text { South } \\
\text { Africa }\end{array}$ & ToCSV & S. lycopersicum ${ }^{a}$ & $99 \%$ & KY290392 & Moodley et al. (2016b) \\
\hline $\begin{array}{l}\text { South } \\
\text { Africa }\end{array}$ & PVY & C. annuum $^{\mathrm{a}}$ & $98 \%$ & KF770835 & Moodley et al. (2014) \\
\hline $\begin{array}{l}\text { South } \\
\text { Africa }\end{array}$ & PVY & S. lycopersicum ${ }^{\mathrm{a}}$ & $85 \%$ & KU236384 & Kisten et al. (2016b) \\
\hline $\begin{array}{l}\text { South } \\
\text { Africa }\end{array}$ & PVY & P. peruviana ${ }^{\mathrm{b}}$ & $96 \%$ & KU695256 & Kisten et al. (2016b) \\
\hline Zimbabwe & IYSV & A. $c e p a^{\mathrm{a}}$ & $97 \%$ & KT271469 & Karavina et al. (2016a) \\
\hline Zimbabwe & IYSV & A. sativum ${ }^{\mathrm{a}}$ & $97 \%$ & KT732272 & Karavina et al. (2016b) \\
\hline Zimbabwe & IYSV & A. ampeloprasum ${ }^{\mathrm{a}}$ & $99 \%$ & KT732273 & Karavina et al. (2016b) \\
\hline Zimbabwe & IYSV & A. hybridus & $98 \%$ & KX192315 & $\begin{array}{l}\text { Karavina and Gubba } \\
\text { (2016) }\end{array}$ \\
\hline Zimbabwe & IYSV & A. spinosus ${ }^{b}$ & $98 \%$ & KX192325 & Karavina et al. (2016) \\
\hline Zimbabwe & IYSV & E. indica ${ }^{\mathrm{b}}$ & $98 \%$ & KX192321 & Karavina et al. (2016) \\
\hline Zimbabwe & TSWV & C. annuum $^{\mathrm{a}}$ & $99 \%$ & KU671049 & Karavina et al. (2016c) \\
\hline Zimbabwe & TSWV & C. moschata ${ }^{\mathrm{a}}$ & $99 \%$ & KT732271 & Karavina et al. (2016d) \\
\hline Zimbabwe & PVY & C. annuum $^{a}$ & $89 \%$ & KU695465 & Karavina et al. (2016c) \\
\hline
\end{tabular}

${ }^{\text {aVegetable crop }}$

'Weed

${ }^{\mathrm{C}}$ An annual flowering plant

N/A - Data not available currently

(non-translated region), coat protein gene (CP) and part of the nuclear inclusion body $(\mathrm{NIb})$ revealed that the infecting isolate is a recombinant $\mathrm{PVY}^{\mathrm{C}}$ strain with spliced $\mathrm{O}$ fragments previously identified on pepper in a 2010 survey of pepper and tomato farms in KwaZulu Natal, South Africa (Ibaba and Gubba 2011). Moodley et al. (2014) provide a comprehensive analysis of the isolate PVY-JVW186 (GenBank Accession no. KF770835) which remains the predominant strain infecting tomato and pepper crops presently (Kisten et al. 2016). The use of antibodies and sequence data allows for the detection of recombinant strains. Recombination can be confirmed using software such as recombination detection program (RDP) (http://en.bio-soft.net/tree/RDP.html). Strain differentiation and recombinant 
Table 4.4 Farmer perceptions on emerging insect pests

\begin{tabular}{l|c|c|c|c|c|c|l}
\hline Farmer response & NR1 & NR2 & NR3 & NR4 & NR5 & Mean & P value \\
\hline Strongly agree & 40 & 52 & 42 & 24 & 26 & 37 & a \\
\hline Agree & 58 & 48 & 54 & 70 & 66 & 59 & a \\
\hline Disagree & 2 & 0 & 4 & 6 & 8 & 4 & a \\
\hline Total & 100 & 100 & 100 & 100 & 100 & 100 & \\
\hline
\end{tabular}

${ }^{a}$ there was a significant difference at $\mathrm{P}<0.01$, NS-No Significant difference at $\mathrm{P}<0.05$

analysis are important for viruses such as PVY in which fitness and host resistance breakdown may be heightened. PVY isolates from Zimbabwe were not tested at this stage.

\subsubsection{Zimbabwean Farmers' Perceptions}

Most farmers (59\%) across all the natural regions in Zimbabwe had the perception that there were emerging insect pests as a result of climate change while $37 \%$ strongly agreed that the climate was changing. Only $4 \%$ disagreed with the notion that there are emerging insect pests. Within the NR there was a significant difference in the response of farmers $(\mathrm{P}<0.05)$. A Post Hoc analysis indicated that there was no significant difference in farmer's responses between NR1, NR2, and NR3. There was a significant difference in farmer's perceptions to the emergence of new insect pests between farmers in NR2 and those in NR4 and NR5. Between NR4 and NR5, the responses of the farmers were statistically similar $(\mathrm{P}<0.05)$ (Table 4.4). Insects such as aphids stem borers, bollworms, diamondback moth (DBM), cutworms, red spider mites, termites, whiteflies and leaf miners were found to be among the key pests in the various agro-ecological regions of the country. Aphids and stem borers were predominant in all five natural regions. Bollworms were identified as the key pest in NR3 and termites were more dominant in NR4 and NR5 compared to NR1, NR2 and NR3 (Table 4.5). According to farmers in Zimbabwe, whiteflies and aphids were among the major insect vectors identified in all the natural regions.

\subsection{Discussion}

Recently, the onset of new and emerging pests and disease in Southern Africa and elsewhere has raised global concern. Although farming practices may have a significant influence on pest populations, underlying issues relating to global climate change are not well understood. The essentially ectothermic nature of insects indicates that temperature is the single most important factor that drives their physiological processes. Minor changes in temperature can produce catastrophic effects on 
Table 4.5 Ranking of five key pests per agro-ecological zone as perceived by the smallholder farmers in order of importance

\begin{tabular}{l|l|l|l|l|l|l|l|l|l|l}
\hline Ranking & NR1 & No. & NR2 & No. & NR3 & No. & NR4 & No. & NR5 & No. \\
\hline 1 & Aphids & 13 & Aphids & 16 & Bollworms & 20 & RSM & 17 & Termites & 18 \\
\hline 2 & Stem borer & 11 & DBM & 12 & Aphids & 13 & Termites & 11 & Stem borer & 10 \\
\hline 3 & Cutworms & 10 & Stem borer & 9 & DBM & 7 & Aphids & 8 & DBM \\
\hline 4 & Whiteflies & 9 & Cutworms & 7 & Cutworms & 6 & Whiteflies & 8 & Aphids & 7 \\
\hline 5 & Leaf miners & 7 & Bollworms & 6 & Stem borer & 4 & Stem borer & 6 & Bollworms & 6 \\
\hline Total & & 50 & & 50 & & 50 & & 50 & & 50 \\
\hline
\end{tabular}

Notes: No refers to number of respondents, DBM-Diamond Back Moth. RSM-Red Spider Mite

Source (Survey data 2015) 
natural and agricultural ecosystems with possible outcomes of an ecological cascade. The drastic reduction or extinction of a species as a result of anthropogenic activity, sudden environmental changes or extreme weather events, pesticide misuse and a general lack of knowledge may in part or collectively accelerate pest outbreaks and disease epidemics.

This study was undertaken to assess pest populations and vector-borne disease on commercial, smallholder, and emerging farms in South Africa and Zimbabwe. It seems that the topic of pests and diseases is a niche for vegetable crop production in Southern Africa. Bridging the knowledge gap between researchers, farmers, and government extension workers is of primary concern for the development of appropriate pest management systems. Overall, the majority areas surveyed during the 2015/2016 growing seasons have indicated the struggle endured by the agricultural industry to reduce the biotic influence on the yield and quality of fresh produce.

Insects directly damage crops through feeding; however, some species transmit viral pathogens that cause physiological disorders such as stunting and fruit deformation, flower abscission, necrosis, and chlorophyll reduction which results in billions of dollars in crop losses worldwide. Apart from a few commercial farms in South Africa, the majority of farming communities experienced high pest pressure, low yields and little to no profit margins. Plagued by drought, crops in Zimbabwe were overwhelmed by an array of pests and diseases that crippled the country's agricultural sector.

Southern Africa recently experienced one of the worst droughts in history which was heightened by the El Niño phenomenon that threatened the livelihoods of many farmers (ReliefWeb 2015). The higher temperature/low rainfall pattern led to a surge of economically important insect pests such as whiteflies, aphids, thrips, termites and red spider mites. The impact on crop vulnerability as a result of intensified biotic and abiotic stress may have contributed to the emergence of a disease such as Tomato torrado virus (ToTV) (Table 4.3) which we reported for the first time from the mainland African continent (Moodley et al. 2016b). This disease was concentrated in the northern parts of South Africa where temperatures are generally higher, and conditions are dry. According to the commercial farmers and scouts who have been farming the land for decades, they had never observed the burnt-like necrotic symptoms on tomato crops infected with whitefly-transmitted ToTV.

ToTV was also identified on symptomatic weeds growing along rows of greenhouse and field grown tomatoes. Datura stramonium among many other species (Table 4.2) that are widely distributed in South Africa tested positive for similar viruses identified on nearby crops. Weeds are a source of inoculum and overwintering mechanism that harbor insect vectors and viral pathogens that subsequently infect crops from one growing season to the next. Weeds therefore significantly contribute to virus epidemiology in agricultural systems and must be controlled using stringent methods. Padalia et al. (2015) explained the effect of climate change on the distribution of weed species to previously uninhabited areas which pose a dire risk to global agriculture.

All the viruses currently identified on crops and weeds in Zimbabwe were first reports. This stems from a lack of research facilities and expertise within the coun- 
try. Collaborative studies with other countries will create a better perspective on the movement of pests and disease within the global agricultural sector. Educating farmers in Southern Africa on pest and disease epidemiology under current and future scenarios of global climate change can lower the risk of outbreaks through adaptation and revised farming practices using area-specific integrated pest management systems.

An increase in the prevalence of insect pests such as whiteflies, aphids, and bollworms may also result from their polyphagous feeding habit of field and horticultural crops (Sharma et al. 2011). Selvaraj and Pandiara (2013) explained that the polyphagous nature of insect species such as whiteflies and aphids may become dominant pests of a larger variety of crop species under future climate warming scenarios. Insects adapt rapidly to environmental changes which directly influence their population dynamics. Pesticide treadmills offset the balance of natural enemies whilst stimulating the buildup of resistant genotypes that increase the risk of outbreaks.

In other surveys of economically important pests such as termites and stem borers in Zimbabwe, an increase in termites was reported during mid-season drought periods on agricultural lands (Kladiviko et al. 2008). In a related study, the activities of termites were found to be influenced by soil moisture as low densities of the termites were observed in high rainfall areas as well as wetlands while higher densities were observed in the more arid areas (Nhamo 2007). The presence of cereals and the ability of stem borers to inhabit wild grassy hosts could also have led to its increased incidence across the country's natural regions (Calatayud et al. 2014). In NR4 and NR5, the higher prevalence of stem borers could have resulted from the cultivation of various drought tolerant grass cereals such as sorghum, rapoko and millet. The emergence of new insect pests as perceived by the respondents could have been due to the introduction of new crops as a way of adapting to changes in climatic conditions (Gregory et al. 2009). Studies carried out by Comoe and Siegrist (2015) and Menace et al. (2015) showed that climate change has the potential to alter the distribution, incidence, and intensity of plant pests and diseases and cause new crop insects to emerge.

\subsection{Summary and Policy Directions}

The life cycle of indigenous pests within a given region is likely to be impacted under climate change leading to higher number of generations per season. Increasing global trade of plants and plant products fosters also introduction and dissemination of exotic pests from one region to another and climate change will favour their establishment through the new regions which were previously unfavorable to their adaptation. This means that the pressure of pests in agriculture will increase both in space and time due to both native and invasive species. Hence durable plant protection strategies are needed to tackle such challenges. Although climate change is expected to have a significant impact on agriculture in Southern Africa by 
influencing the stability of crop yields, scientific information on new pests is lacking or is in its infancy. Research based on broader collaborative approach should be made in order to develop anticipatory adaptive strategies resulting in more resilient cropping systems. To this aim, intraregional, interregional, transnational and global networking of researchers and stakeholders is an effective way to better use the limited resources needed to address this central twenty-first century challenge.

\section{References}

Accotto, GP, Navas-Castillo, J, Noris, E, Moriones, E, Louro, D (2000). Typing of Tomato yellow leaf curl viruses in Europe. European Journal of Plant Pathology 106(2):179-186.

Asala, S, Alegbejo, MD, Kashina, BD, Banwo, OO, Shinggu, CP (2014). Viruses in weeds in Dioscorea yam fields in Nigeria. African Crop Science Journal 22(2):109-115.

Ben Khalifa, M, Simon, V, Marrakchi, M et al (2009). Contribution of host plant resistance and geographic distance to the structure of Potato virus Y (PVY) populations in pepper in northern Tunisia. Plant Pathology 58:763-772.

Calatayud, PA, Le Ru, BP, van den Berg, J, Schulthess, BF (2014). Ecology of the African Maize Stalk Borer, Busseola fusca (Lepidoptera: Noctuidae) with Special Reference to Insect-Plant Interaction. Insects 5:539-563.

Chen, J, Chen, J, Adams, MJ (2001) A universal PCR primer to detect members of the Potyviridae and its use to examine the taxonomic status of several members of the family. Archives of Virology 146:757-766.

Chen, TC, Li, JT, Lin, YP et al (2012) Genomic characterization of Calla lily chlorotic spot virus and design of broad spectrum primers for detection of tospoviruses. Plant Pathology 61:183-194.

Clements, DR, DiTommaso, A, Hyvönen, T (2014) Ecology and management of weeds in a changing climate. In: Recent Advances in Weed Management. Chauhan, BS, Mahajan, G (eds). Springer Science. New York, United States.

Comoe, R, Siegrist, M (2015) Relevant drivers of farmers' decision behavior regarding their adaptation to climate change: a case study of 2 regions in Cote d'Ivore. Mitigation and Adaptation Strategies for Global Change 20:179-199.

Fernandes, FR, de Albuquerque, LC, de Britto Giordano, L et al (2008). Diversity and prevalence of Brazilian bipartite begomovirus species associated to tomatoes. Virus Genes 36:251-258.

Goyal, G, Gill, HK, McSorley, R (2015) Common weed hosts of insect-transmitted viruses of Florida vegetable crops. UF/IFAS Extension. ENY-863. University of Florida, United States. http://edis.ifas.ufl.edu.

Gregory, P.J., Johnson, S.N., Newton, A.C., \& Ingram, J.S.I. (2009). Integrating pests and pathogens into the climate change/food security debate. Journal of Experimental Botany 60:28272838. https://doi.org/10.1093/jxb/erp080.

Karavina, C, Gubba, A (2016). Amaranthus sp. and Eleusine indica are natural hosts of Iris yellow spot virus in Zimbabwe. Plant Disease https://doi.org/10.1094/PDIS-05-16-0652-PDN.

Karavina, C, Ibaba, JD, Gubba, A (2016a). First Report of Iris yellow spot virus Infecting Onion in Zimbabwe. Plant Disease 100(1):235.

Karavina, C., Ibaba, J.D., Gubba, A. and Pappu, H.R. (2016b). First Report of Iris yellow spot virus Infecting Garlic and Leek in Zimbabwe. Plant Disease 100(3):657.

Karavina, C, Ximba, S, Ibaba, JD, and Gubba, A (2016c). First report of a mixed infection of Potato virus $Y$ and Tomato spotted wilt virus on pepper (Capsicum annuum) in Zimbabwe. Plant Disease 100(7):1513.

Karavina, C, Ibaba, JD, Gubba, A (2016d). First report of Tomato spotted wilt virus infecting butternut squash (Cucurbita moschata Duch.) in Zimbabwe. Plant Disease 100(4):870. 
Katsaruware-Chapoto RD, Mafongoya PL and Gubba A. (2017) Responses of Insect Pests and Plant Diseases to Changing and Variable Climate: A Review Journal of Agricultural Science 9:160-168.

Kisten, L, Moodley, V, Gubba, A, Mafongoya, PL (2016) First Detection of (TSWV) on in South Africa. Plant Disease 100(10):2176-2176.

Kisten, L, Moodley, V, Gubba, A, Mafongoya, PL (2016a) First Detection of Tomato spotted wilt virus (TSWV) on Amaranthus thunbergii in South Africa. Plant Disease 100(7):2176.

Kisten, L, Moodley, V, Gubba, A, Mafongoya, PL (2016b) First Report of Potato Virus Y (PVY) on Physalis peruviana in South Africa. Plant Disease 100(7):1511.

Ibaba, JD, Gubba, A (2011) Diversity of Potato Virus Y isolates infecting solanaceous vegetables in the province of KwaZulu-Natal in the Republic of South Africa. Crop Protection 30(11):1404-1408.

IPCC (2007) Climate Change 2007: Synthesis Report. Contribution of Working Groups I, II and III to the Fourth Assessment Report of the Intergovernmental Panel on Climate Change [Core Writing Team, Pachauri, R.K and Reisinger, A. (eds.)]. IPCC, Geneva, Switzerland, 104 pp.

Kladiviko, EJ, Savabi, MR, Golabi, AA (2008) Infiltration characteristics of no till vs. conventional tillage in Indiana and Illinois farm fields. In Goddard, T Zoebisch, MA, Gan, YT et al. (eds) No-till farming systems Special publication No. 3. pp. 289-300. World Association of Soil and Water Conservation, Bangkok.

Kwon, S, Choi, G, Yoon, J et al (2016) Identification of Leonurus sibiricusas a weed reservoir for three pepper-infecting viruses. Plant Pathology Journal 32(1):65-69.

Menace, L, Colson, G, Rafaelli, R (2015) Climate change beliefs and perceptions of agricultural risks: An application of the exchangeability method. Global Environmental Change 35:70-81.

Moodley, V, Ibaba, JD, Naidoo, R, Gubba, A (2014) Full-genome analyses of a Potato virus $Y$ (PVY) isolate infecting pepper (Capsicum annuum L.) in the Republic of South Africa. Virus Genes 49:466-476.

Moodley, V, Gubba, A, Mafongoya, PL (2016a). First Report of Tomato torrado virus on Tomato (Solanum lycopersicum) in South Africa. Plant disease 100(1):231.

Moodley, V, Gubba, A, Mafongoya, PL (2016b) Occurrence of Tomato chlorosis virus (ToCV) on Datura stramonium Near Tomato Crops (Solanum lycopersicum) in South Africa. Plant disease 100(7):1512.

Nhamo, N (2007) The contribution of different fauna communities to improved soil health: A case of Zimbabwean soils under conservation agriculture. PhD. thesis, University of Bonn, Ecology and Development Series 56:131.

Oerke, EC (2006) Crop Losses to Pests. Joumal of Agricultural Science 144:31-43.

Padalia, H, Srivastava, V, Kushwaha, SPS (2015). How climate change might influence the potential distribution of weed, bushmint (Hyptis suaveolens). Environmental Monitoring and Assessment 187:210.

Peters, K, Breitsameter, L, Gerowitt, B (2014) Impact of climate change on weeds in agriculture: a review. Agronomy for Sustainable Development 34:707-721.

Prajapat, R, Marwal, A, Gaur, RK (2014). Begomovirus associated with alternative host weeds: A critical appraisal. Archives of Phytopathology and Plant Protection 47(2):157-170.

ReliefWeb. (2015). Southern Africa Humanitarian Outlook 2015/2016: Special Focus on El Niño - World I ReliefWeb. Retrieved January 25, 2016, from http://reliefweb.int/report/world/ southern-africa-humanitarian-outlook-20152016-special-focus-el-ni-o

Selvaraj, G, Pandiara, T, (2013) Potential impacts of recent climate change on biological control agents in agro-ecosystem: A review. International Journal of Biodiversity and Conservation 5(12):845-852.

Sharma, KC, Bhardwaj, SC, Sharma (2011). Systematic studies, life history and infestation by Helicoverpa armigera on tomato in semi-arid region of Rajastan. Biological Forum - An International Journal 3(1):52-56.

Tamura K, Stecher G, Peterson D et al (2013) MEGA6: Molecular Evolutionary Genetics Analysis version 6.0. Molecular Biology and Evolution 30: 2725-2729. 
Van Bogaert, N, Smagghe, G, De Jonghe, K (2015). The role of weeds in the epidemiology of pospiviroids. Weed Research 55:631-638.

Verbeek, M, Tang, J, Ward, LI (2012). Two generic PCR primer sets for the detection of members of the genus Torradovirus. Journal of Virological Methods 185:184-188.

Wintermantel, WM, Hladky, LL (2010). Methods for detection and differentiation of existing and new crinivirus species through multiplex and degenerate primer RT-PCR. Journal of Virological Methods 170:106-114. 